УДК 553.041:553.22

\title{
ЗОЛОТО В РУДАХ ЗОЛОТО-КОЛЧЕДАННОГО МЕСТОРОЖДЕНИЯ АБЫЗ (ЦЕНТРАЛЬНЫЙ КАЗАХСТАН)
}

\author{
Мазуров Алексей Карпович1, \\ akm@tpu.ru
}

\begin{abstract}
Николаева Анастасия Николаевна', nikolaevaanastas759@gmail.com
\end{abstract}

Рудмин Максим Андреевич1, rudminma@tpu.ru

\author{
Якич Тамара Юрьевна', \\ cherkasovatu@tpu.ru
} Рубан Алексей Сергеевич ${ }^{1}$,
ruban@tpu.ru

\author{
Байболова Шынар Жуматаевна², \\ baibolova-sh@mail.ru \\ 1 Национальный исследовательский Томский политехнический университет, \\ Россия, 634050, г. Томск, пр. Ленина, 30. \\ 2 Карагандинский государственный технический университет, \\ Казахстан, 100027, г. Караганда, пр. Нурсултана Назарбаева, 56/1.
}

Актуальность исследования. В Чингиз-Тарбогатайской структурно-формационной зоне известно более 20 золотоколчеданных месторождений. Все месторождения объединяет одна проблема: при обогащении руд значительная часть золота переходит в «пиритный» концентрат и теряется вместе $c$ «хвостами». В целях увеличения извлечения золота нами был детально изучен минеральный состав руд наиболее представительного золото-колчеданного месторождения Абыз. Установлено, что значительная часть золота на месторождении представлена минералом электрумом, который заполняет микротрещины в пирите и халькопирите. При разработке технологической схемы извлечения золота, вероятно, данному факту не было уделено должного внимания, так как считалось, что золото в пирите представлено самородным золотом.

Цель: изучить текстурно-структурные особенности руд, а также установить минеральную форму нахождения золота в рудах месторождения Абыз и его связь с основными сульфидными минералами (пирит, халькопирит, галенит и сфралерит).

Методы исследования включали изучение состава горных пород и руд с использованием минералогического, петрографического, минераграфрического и геохимического анализов.

Результаты. По структурно-текстурным свойствам на месторождении выделены вкрапленные и сплошные руды. Установлено, что основное количество золота, ассоциирующееся в основном с пиритом и редко халькопиритом, связано со сплошными рудами и представлено в минеральной форме. Золотая минерализация сопряжена с процессами березитизации; отложение минералов Аи происходило в рудную стадию минералообразования и связано с золото-сульфидной и золототеллуридной ассоциациями. Преобладающим минералом является электрум AgAu, в меньшей степени диагностируется самородное золото $\mathrm{Au}$ и единично обнаружен петцит $\mathrm{Ag}_{3} \mathrm{AuTe} \mathrm{T}_{2}$ с калаверитом $\mathrm{AuTe}$. Доминирующими минераламиконцентраторами в рудах являются такие сульфиды, как пирит и халькопирит. Причину потери большей части золота в результате фрлотации можно объяснить тем фактором, что низкопробный золотосодержащий минерал электрум AgAu является господствующим.

\section{Ключевые слова:}

Чингиз-Тарбогатайская структурно-формационная зона, золото-колчеданные месторождения, сульфиды, пирит, золото, Центральный Казахстан.

\section{Введение}

Месторождения золото-колчеданных руд в Чингиз-Тарбогатайской структурно-формационной зоне Казахстана известны с бронзового века. Первые сведения о геологическом строении этих месторождений были даны в 1895 г. геологом А.А. Краснопольским, который определил их промышленную ценность. В различные периоды развития горнорудной промышленности в районе были и различные направления использования колчеданных руд. В 1916-1918 гг. руды добывались карьерным способом и использова- лись как бурые железняки, в 1926-1930 гг. эти руды использовались в качестве сырья для сернокислотного производства [1-5].

Планомерное геологическое изучение колчеданных месторождений в Предчингизье было начато в 1926 г. под руководством Н.Т. Кассина, Р.Т. Барукаева и Г.И. Медоева. В результате проведенного изучения в рудах были установлены значительные запасы золота, и с 1933 г. колчеданные месторождения стали рассматриваться как медно-свинцово-цинковые с золотом. В настоящее время золото-колчеданные ме- 
сторождения Предчингизья связывают с формированием энсиматической островной дуги поздней стадии развития. В результате проведенных геологоразведочных работ (1926-1992 гг.) в пределах ЧингизТарбогатайской зоны выявлено более 20 месторождений (Майкаинская группа (А, Б, С, Е, Г), Сувенир, Торткудук, Абыз, Первомайское, Красная Горка, Придорожное, Уч-Тобе, Шоптыколь и др). Руды комплексные, основные компоненты: золото, серебро, медь, цинк, свинец. Значительная часть золота связана с пиритным концентратом. С целью комплексного использования руд нами были изучены руды верхних горизонтов наиболее представительного месторождения Абыз $[6,7]$.

Месторождение Абыз открыто в 1973 г., изучалось В.Г. Тихомировым, И.А. Дороховым, Н.М. Исаевым, Э.С. Файзуллиным, В.Н. Исаевым, А.М. Мызниковым К.Ш. Дюсембаевой, Ф.Ф. Судовцевым, С.Е. Беляевым Н.П. Остробородько, В.М. Шужановым, Б.С. Хамзиным и др. При составлении карты «Полезные ископаемые Казахстана» масштаба 1:1000000 образование месторождения нами было связано с формированием энсиматической островной дуги позднего этапа развития [8]. Месторождение Абыз расположено в зоне влияния Центрально-Казахстанского глубинного разлома. Вмещающими породами является вулканогенно-терригенная толща девонского возраста, которая гидротермально-метасоматическими процессами интенсивно изменена с образованием пропилитовых и березитовых статистически устойчивых минеральных ассоциаций [9-15].

В процессе геологоразведочных работ в пределах зоны метасоматитов выделено 16 рудных тел. Морфология рудных тел сложная, как по простиранию, так и по падению отмечаются раздувы и пережимы, изгибы, апофизы. Протяженность рудных тел по простиранию 80-650 м, по падению 50-220 м, мощность 0,8-30 м. Средние содержания свинца в рудах 0,37\%, цинка $-5,37 \%$, меди - 2,33 \%, золота - 6,6 г/т, серебpa - 64,6 г/т. Руды сложены пиритом, сфалеритом, халькопиритом, галенитом, отмечаются золото, электрум, гессит, алтаит, рутил, ильменит, касситерит, реже петцит, калаверит, ченгуодаит, лаутит, телуровисмутин, нерудные - кварц, серицит, хлорит, кальцит, альбит, эпидот, дикит, кальсилит, микроклин, ортоклаз. Текстуры руд: массивная, прожилкововкрапленная, вкрапленная, полосчатая, пятнистовкрапленная. Общей проблемой для всех золотоколчеданных месторождений Предчингизья являются значительные потери золота с «пиритовыми хвостами» [16-18].

\section{Материал и методика исследования}

Из основных рудных тел были отобраны бороздовые пробы весом от одного до трех килограмм, которые были подвергнуты макроскопическому описанию. При визуальном осмотре образцов отмечался цвет и оттенки пород, текстура, структура и минеральный состав. Отобранные пробы были детально изучены с помощью минераграфического и петрографического исследований. Часть материала проб была подвергну- та минералогическому анализу. Пробы дробились, и из класса $(-0,20+0,12)$ ручным способом (под бинокуляром) отбирались монофракции пирита.

С целью геохимической характеристики были выполнены: масс-спектрометрия с индуктивносвязанной плазмой (ИСП-MC, ELAN DRC-е) и рентрено-флюоресцентный анализ на HORIBA XGT7200. Для обнаружения и выделения генераций кварца использовалась раман-спектроскопия (Thermo Fisher Scientific DXR2).

В целях определения минеральной формы золота, его морфологических особенностей и характера срастания с другими минералами, а также определения состава элементов-примесей была применена сканирующая электронная микроскопия (СЭМ) с локальными энергодисперсионным анализом (Oxford X-Max 50).

Для определения температуры минералообразования изучались газово-жидкие включения в кварце методом гомогенизации с помощью микротермокамеры THMSG-600 с программным обеспечением LinkSys32 производства Linkam.

\section{Результаты и обсуждения}

Нами по текстурно-структурным особенностям на месторождении выделено два типа руд: вкрапленные и сплошные колчеданные [19, 20].

Сплошные руды на 95...98 \% сложены сульфидами. Для руд характерно равномерное, сплошное сложение агрегатов минералов. Данный тип распространен на месторождении наиболее широко.

В составе сульфидов преобладают пирит и халькопирит, суммарно составляя от 70 до 90 \%. Распределение этих минералов в руде неравномерное. В отдельных частях рудного тела халькопирит доминирует над пиритом, достигая $68 . .75 \%$ от общей рудной массы, при этом доля пирита составляет $22 \ldots 30 \%$, иногда, наоборот, доминирует пирит, который составляет $55 . .60 \%$, а на долю халькопирита приходится всего $30 \ldots 40$ \%. Для срастания зерен (выделений) пирита, халькопирита и сфалерита типична аллотриоморфнозернистая структура. Замечено, что реликты пирита сохраняются в других поздних минералах, а именно по результатам сканирования, в ассоциации с халькопиритом. При этом нередко в пирите отмечаются включения халькопирита, галенита и редко сфалерита.

Пирит представлен двумя генерациями - кристаллически-зернистой и метаколлоидной. Кристаллически-зернистый пирит господствует как во вкрапленных, так и в сплошных рудах. В основном зерна размером от 15 до 110 микрон имеют изометричную или неправильную форму.

Пирит изометричной формы, по результатам минералогического исследования, представлен кристаллами кубического, комбинации пентагондодекаэдра и куба и пентагон-додекаэдрического габитуса.

Метаколлоидный пирит встречается редко как в сплошных, так и во вкрапленных рудах и представлен обычно тонкодисперсным агрегатом, реже встречается колломорфно-зональный, глобулярный и др. Размер зерен пирита колеблется в пределах 5-75 микрон. 
Халькопирит нередко накапливается по элементам структуры метаколлоидного пирита или по его трещинкам. В сплошных рудах перекристаллизованная халькопиритовая рудная масса обычно замещает пирит. В свою очередь галенит и сфалерит чаще всего в рудах представлены мелкими вкрапленностями в пирите и халькопирите либо в виде микропрожилков мощностью около 5-15 микрон.

В данном типе руд активно отлагались минералы теллуридов, представленные гесситом $\mathrm{Ag}_{2} \mathrm{Te}$, алтаитом $\mathrm{PbTe}$, теллуровисмутитом $\mathrm{Bi}_{2} \mathrm{Te}_{3}$, ченгуодаитом $\mathrm{Ag}_{9} \mathrm{FeTe}_{2} \mathrm{~S}_{4}$ и раклиджитом $(\mathrm{Bi}, \mathrm{Pb})_{3} \mathrm{Te}_{4}$ в виде овальных и неправильных включений размерностью до 15-20 микрон. Гессит обычно выполняет пространство между пиритом и халькопиритом. Мощность таких прожилков не превышает 10-15 микрон. Единично в сплошных рудах обнаружен лаутит CuAsS непосредственно в ассоциации с пиритом и халькопиритом в виде прожилковидного аллотриоморфного выделения и овальные включения касситерита $\mathrm{SnO}_{2}$. Нерудная минерализация представлена кварцем и кальцитом.

Вкрапленные руды характеризуются преобладанием нерудного материала над рудным, на 40 \% сложены сульфидами и на 60 \% нерудными минералами. В составе сульфидов преобладают пирит и сфалерит, суммарно составляя до $35 . .38$ \%. Распределение этих минералов в руде неравномерное. Чаще всего пирит доминирует над сфалеритом, составляя примерно $22 . .30 \%$

Пирит, так же как и в сплошных рудах, представлен кристаллически-зернистой и метаколлоидной генерацией, промежутки между которыми выполнены кварцем, карбонатами и реже сфалеритом. Кристаллически-зернистый пирит преобладает, размер его зёрен колеблется от $0,1 \times 3$ до $4 \times 6,5$ мм. Кроме того, отдельные зерна пирита интенсивно раздроблены, трещины расположены поперек удлинения зерен. Часто по трещинам дробления в зёрнах пирита развиваются сфалерит и в меньшей степени халькопирит. Мощность прожилков достигает 0,01...0,2 мм. В процентном содержании сфалерит составляет $5 \ldots 12 \%$ от общей рудной массы. Зачастую пирит секут прожилки мощностью от 0,01 до 0,5 мм, выполненные сфалеритом. Обнаружены случаи, когда данный минерал ассоциирует с халькопиритом и галенитом в виде аллотриоморфнозернистых скоплений, приуроченных к межзерновым пространствам пирита. Вкрапленность пирита и халькопирита наблюдается как в свободном виде, так и в срастании друг с другом обычно в кварце, реже в микроклине и ортоклазе. Иногда наблюдается обрастание глобулитового агрегата пирита колломорфно-зональными каёмками, а в промежутках сферических поверхностей развивается тонкозернистый пирит. Между глобулями пирита выделяются мелкие включения сфалерита, которые замещают пирит.

В результате последовательного выделения сульфидов образована каемочная структура. Образуется она в результате того, что более поздний по времени выделения сфалерит нарастает на выделения пирита, образуя невыдержанные по мощности и прерывистые каемки.
Галенит в описываемом типе руд представлен в резко подчинённом количестве $(1 \ldots 2 \%)$. Минерал развит в виде разнообразной формы включений, представляющих собой единичные аллотриоморфные зерна в пирите или их скопления. Размеры отдельных зерен колеблются в пределах 10 микрон.

Во вкрапленных рудах второстепенные минералы представлены гесситом $\mathrm{Ag}_{2} \mathrm{Te}$, рутилом $\mathrm{TiO}_{2}$, ильменитом $\mathrm{FeTiO}_{3}$, цирконом $\mathrm{ZrSiO}_{4}$ а также монацитом $(\mathrm{La}, \mathrm{Ce}, \mathrm{Nd}) \mathrm{PO}_{4}$ и тернемобитом (Ce)-(Ce,La, $\left.\mathrm{Nd}) 2 \mathrm{Al}\left(\mathrm{SiO}_{4}\right)_{2}(\mathrm{OH})\right)$. Гессит, так же как и во вкрапленных рудах, представлен прожилкодиными выделениями, заполняющими пустоты в пирите. Остальные минералы представлены неправильными зёрнами размером до 15 микрон.

По результатам проведенных исследований нами составлена парагенетическая схема минералообразования (таблица 1) [21-25].

Руды месторождения Абыз были сформированы в три стадии:

1) дорудную березитовую;

2) рудную:

- золото-сульфидная ассоциация;

- золото-теллуридная ассоциация;

3) пострудную кварц-кальцитовую.

Дорудные прочессы выражены в березитизации, представленной кварц-серицитовыми метасоматитами. В дорудную березитовую стадию активно отлагались такие минералы, как кварц, серицит и кальцит. В меньшей степени формировались ортоклаз и микроклин. В завершении данной стадии отлагался пирит-1. Температура образования дорудной стадии определена К.Ш Дюсембаевой в 1992 г. [16] и равняется $400-450{ }^{\circ} \mathrm{C}$.

В пределах рудной стадии выделено две ассоциации: золото-сульфидная и золото-теллуридная.

В золото-сульфидную ассочиащию формировались главные рудные минералы (пирит-2, халькопирит, сфалерит и галенит), а также кварц-2. На завершении стадии отлагались монацит с тернемобитом и в весьма малом количестве накапливались такие минералы, как рутил, ильменит, касситерит и лаутит. Рудная минерализация на протяжении всей стадии представлена электрумом и самородным золотом, которые находились в тесной связи с пиритом-2 и халькопиритом.

Непосредственно для золото-сульфидной ассоциации температура минералообразования была определена нами на основе парагенетической ассоциации сфалерита и халькопирита.

Кристаллическая структура халькопирита весьма сходна с таковой сфалерита. Поэтому с данными минералами часты ориентированные срастания не только при распаде и замещении, но и при одновременном образовании простой временной последовательности.

Э. Ингерсоном в 1985 г. было установлено, что температура образования твердых растворов сфалерита и халькопирита равняется $350-400{ }^{\circ} \mathrm{C}$ [26].

В табл. 1 видно, что выделенные генерации пирита присутствуют как в березитах (пирит-1), так и в рудах (пирит-2). Объясняется это тем, что дорудная стадия расположена на небольшом удалении от центральной части рудных тел, что хорошо видно по перекрытию температурных диапазонов. 
Таблица 1. Парагенетическая схема минералообразования

Table 1. Paragenetic scheme of mineral formation

\begin{tabular}{|c|c|c|c|c|}
\hline Этапы/Stages & \multicolumn{4}{|c|}{ Золото-колчеданно-полиметаллический/Gold-pyrite-polymetallic } \\
\hline Стадии/Substages & Дорудная/Pre-ore & \multicolumn{2}{|c|}{ Рудная/Ore } & Пострудная/Post-ore \\
\hline $\begin{array}{c}\text { Минералы } \\
\text { Minerals }\end{array}$ & $\begin{array}{c}\text { Березитовая } \\
\text { Alteration halo }\end{array}$ & $\begin{array}{c}\text { Золото-сульфидная } \\
\text { Gold-sulfide }\end{array}$ & $\begin{array}{c}\text { Золото-теллуридная } \\
\text { Gold-telluride }\end{array}$ & $\begin{array}{c}\text { Кварц-карбонатная } \\
\text { Quartz-carbonate }\end{array}$ \\
\hline $\begin{array}{l}\mathrm{T}^{\circ} \mathrm{C} \text { стадии } \\
\text { Stage } \mathrm{T}^{\circ} \mathrm{C}\end{array}$ & $400-450$ & $350-400$ & 250 & $<250$ \\
\hline Кварц/Quartz & & & & \\
\hline Кальцит/Calcite & & & & \\
\hline Ортоклаз/Orthoclase & & & & \\
\hline $\begin{array}{l}\text { Микроклин } \\
\text { Microcline }\end{array}$ & & & & \\
\hline Серицит/Sericite & & & & \\
\hline $\begin{array}{l}\text { Халькопирит } \\
\text { Chalcopyrite }\end{array}$ & & & & \\
\hline Пирит/Pyrite & & & & \\
\hline Сфалерит/Sphalerite & & & & \\
\hline Галенит/Galena & & & & \\
\hline Рутил/Rutile & & & & \\
\hline Ильменит/Ilmenite & & & & \\
\hline Касситерит/Cassiterite & & & & \\
\hline Лаутит/Lautite & & & & \\
\hline Электрум/Electrum & & & & \\
\hline $\begin{array}{l}\text { Самородное золото } \\
\text { Native gold }\end{array}$ & & & & \\
\hline Петцит/Petzite & & & & \\
\hline Калаверит/Calaverite & & & & \\
\hline Кюстелит/Kyustelite & & & & \\
\hline Гессит/Hessite & & & & \\
\hline $\begin{array}{l}\text { Tеллуровисмутит } \\
\text { Tellurobismutite }\end{array}$ & & & & \\
\hline Алтаит/Altaite & & & & \\
\hline $\begin{array}{l}\text { Ченгуодаит } \\
\text { Chenguodaite }\end{array}$ & & & 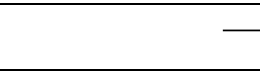 & \\
\hline $\begin{array}{l}\text { Раклиджит } \\
\text { Rucklidgeite }\end{array}$ & & & $\ldots$ & \\
\hline $\begin{array}{l}\text { Tернемобит } \\
\text { Tornebohmite }\end{array}$ & & & & \\
\hline Монацит/Monazite & & & & \\
\hline Кальсилит/Kalsilite & & & & \\
\hline Дикит/Dickite & & & & \\
\hline Цеолиты/Zeolites & & & & \\
\hline
\end{tabular}

Во вторую рудную ассоциацию, непосредственно золото-теллуридную, в большом количестве отлагались теллуриды серебра (гессит), монацит и тернемобит, а также образовывались такие минералы, как алтаит, кюстелит, раклиджит и теллуровисмутит. Золотая минерализация представлена петцитом и калаверитом.

Для определения температуры образования золото-теллуридной ассоциации были изучены флюидные включения в кварце методом гомогенизации [27-29].

Установлено, что температура гомогенизации газово-жидких включений в кварце равняется $\mathrm{T}_{\mathrm{h}}=250^{\circ} \mathrm{C}$.

Завершает процесс минералообразования пострудная стадия, с которой связано образование кварцкальцитовых прожилков. Прожилки пострудной стадии пересекают минеральные агрегаты ранних стадий. В пустотах и крупных трещинах отлагались кальсилит и дикит. Весьма редко в данную стадию встречаются цеолиты. Температура образования - менее $250{ }^{\circ} \mathrm{C}$.

При технологическом исследовании руд установлено, что большая часть золота связана с сульфидами (пирит, галенит, халькопирит, сфалерит), которые диагностируются в составе пиритного концентрата (табл. 2).
Таблица 2. Состав пиритного концентрата месторождения Абыз

Table 2. Chemical composition of pyrite concentrate from the Abyz deposit

\begin{tabular}{|c|c|c|c|}
\hline $\begin{array}{l}\text { Компоненты } \\
\text { Components }\end{array}$ & $\begin{array}{c}\text { Содержа- } \\
\text { ние, \% } \\
\text { Content, \% }\end{array}$ & $\begin{array}{l}\text { Компоненты } \\
\text { Components }\end{array}$ & $\begin{array}{c}\text { Содержа- } \\
\text { ние, \% } \\
\text { Content, \% }\end{array}$ \\
\hline Кремний/Silicon & 5,83 & Мышьяк/Arsenic & 0,12 \\
\hline $\begin{array}{l}\text { Железо общее } \\
\text { Iron total }\end{array}$ & 38,30 & Медь/Copper & 1,15 \\
\hline $\begin{array}{l}\text { Cepa общая } \\
\text { Sulfur total } \\
\end{array}$ & 45,20 & Цинк/Zinc & 2,46 \\
\hline $\begin{array}{l}\text { Алюминий } \\
\text { Aluminum }\end{array}$ & 0,74 & Свинец/Lead & 0,34 \\
\hline \begin{tabular}{|l|} 
Титан \\
Titanium \\
\end{tabular} & 0,25 & $\begin{array}{l}\text { Двуокись углерода } \\
\text { Carbon dioxide }\end{array}$ & 0,17 \\
\hline $\begin{array}{l}\text { Магний+Кальций } \\
\text { Magnesium+Calcium }\end{array}$ & 0,90 & $\begin{array}{c}\text { Золото, г/т } \\
\text { Gold, g/t }\end{array}$ & 4,85 \\
\hline \begin{tabular}{|l|} 
Марганец \\
Manganese
\end{tabular} & 0,25 & $\begin{array}{c}\text { Серебро, г/T } \\
\text { Silver, g/t }\end{array}$ & 40,00 \\
\hline
\end{tabular}

Нами выполнен пересчёт по химическому составу концентрата, где весовой процент каждого сульфида составил: пирит - 36,53 \%, халькопирит - 36,28 \%, галенит - 14,05 \%, сфалерит - 13,12 \% (табл. 3). При 
пересчете на весовой процент нерудные минералы не учитывались, так как они присутствуют в незначительных количествах и в сумме составляют около 1 \%. Полученные данные говорят о том, что концентрат правильнее именовать сульфидным, а не пиритным.

Таблица 3. Весовой процент сульфидов

Table 3. Weight percentage of sulfides

\begin{tabular}{|c|c|c|c|}
\hline $\begin{array}{c}\text { Сульфиды } \\
\text { Sulphides }\end{array}$ & $\begin{array}{c}\text { Молеку- } \\
\text { лярный вес } \\
\text { Molecular } \\
\text { weight }\end{array}$ & $\begin{array}{c}\text { Молекулярный вес * Содер- } \\
\text { жание } \\
\text { Molecular weight * Content }\end{array}$ & $\begin{array}{c}\text { Весо- } \\
\text { вой, \% } \\
\text { Weight, \% }\end{array}$ \\
\hline $\mathrm{FeS}_{2}$ & 87,90 & $87,9 *(25,53+16,95)=37,30$ & 36,53 \\
\hline $\mathrm{PbS}$ & 239,30 & $239,3 *(0,34+5,65)=14,33$ & 14,05 \\
\hline $\mathrm{ZnS}$ & 97,40 & $97,4 *(2,46+11,3)=13,40$ & 13,12 \\
\hline $\mathrm{CuFeS} \mathrm{S}_{2}$ & 151,50 & $151,5^{*}(0,15+13+11,3)=37,04$ & 36,28 \\
\hline $\begin{array}{c}\text { Итого } \\
\text { Total }\end{array}$ & 576,10 & 102,10 & 99,98 \\
\hline
\end{tabular}

В результате дальнейшего изучения руд было установлено, что золото в основном связано с мине- ралом электрумом и в меньшей степени представлено в виде самородного высокопробного (рис. 1, 2).

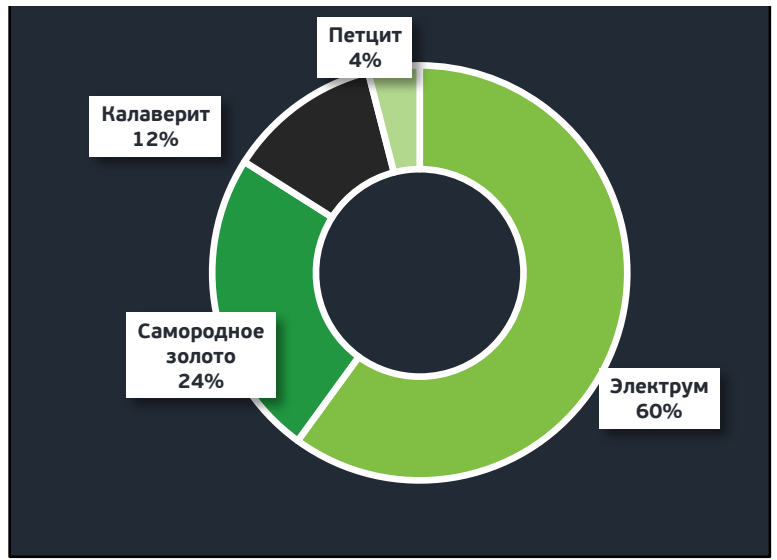

Рис. 1. Золотая минерализация в рудах

Fig. 1. Gold mineralization in ores

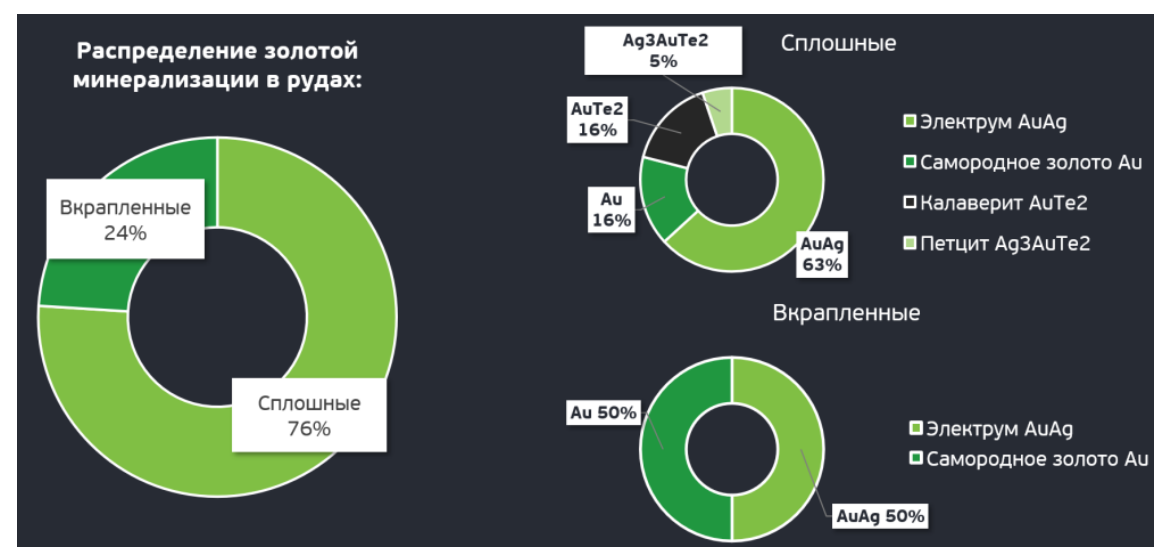

Pис.2. Распределение золотой минерализации в рудах

Fig. 2. Distribution of gold mineralization in ores

Электрум в основном концентрируется в пирите и в меньшей степени в халькопирите. Золото в связи с сульфидами определяется в рудных минералах в виде каплевидных включений и мелких неправильных зерен, но чаще всего оно выполняет межзерновые пространства, образуя тончайшие нитевидные жилки, петельчатые скопления и реже мелкие зерна, обычно концентрирующиеся по периферии зёрен сульфидов.

По данным сканирующей электронной микроскопии в составе выделений электрума (AuAg), который относится к интерметаллическим соединениям, содержания $\mathrm{Au}$ колеблются в пределах 61,5...72 \% и $\mathrm{Ag}=28 \ldots 38,5 \%$, что четко указывает на наличие в рудах преимущественно низкопробного золота. Форма выделений обычно прожилковидная, редко представлена в виде изометричных и неправильных зёрен. Чаще всего электрум заключён между зернами пирита и халькопирита (рис. 3), также в процессе сканирования руд обнаружены случаи нахождения минерала в трещинах пирита. Мощность выделений не превышает 3 микрон, а длина - 30 микрон.
Самородное золото Аи обнаружено в рудах в меньшей степени. Форма выделения распространена как в виде прожилковидных выделений, заполняющих пустоты или трещины, так и в виде неправильных зерен. В ходе сканирования руд были выявлены случаи развития неправильных зерен золота, концентрирующихся по периферии сульфидов. Выделения по своим размерам не превышают 3,85 микрон (рис. 4).

Помимо этого, выявлены случаи, когда в халькопирите, выполняющем межзерновые пространства в пирите, обнаружены неправильные зерна самородного золота размером $18 * 9$ микрон (рис. 5).

Помимо самородного золота, в процессе изучения руд в пирите обнаружены теллуриды золота, по своему химическому составу $(\mathrm{Au}=40 \ldots 43 \%, \mathrm{Te}=57 . .60 \%)$ представленные калаверитом $A и T e_{2}$ (рис. 6). Обнаруженные включения овальных зёрен по своим размерам не превышают 1,5 микрон.

Редко в рудах диагностируется минерал петцит $\mathrm{Ag}_{3} \mathrm{AuTe}_{2}(\mathrm{Au}=25 \ldots 26 \%$, Te=32...33 \%, Ag=41..42\%) в виде неправильных включений размерностью около 1,45 микрон (рис. 7). 


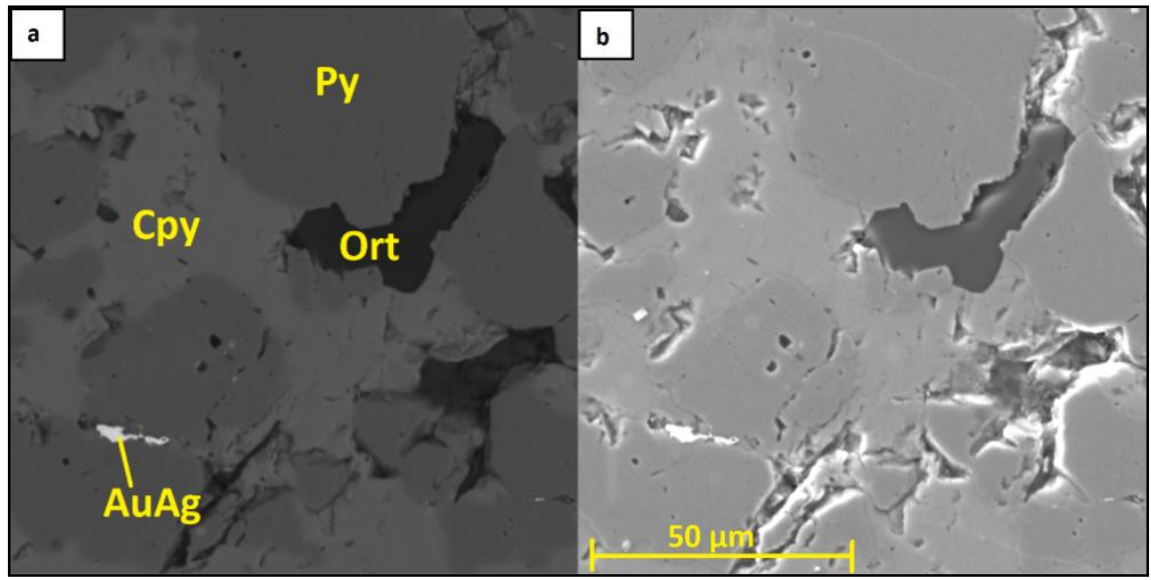

Рис. 3. Изображение сканирующего электронного микроскопа в обратно рассеянных (a) и вторичных (b) электронах, демонстрирующее прожилковидную форму зерна электрума (АиAg), заполняющего пустоты между халькопиритом (Сру) и пиритом (Рy), в ассочиащии с ортоклазом (Ort)

Fig. 3. SEM image in backscattered (a) and secondary (b) electrons, demonstrating the vein-like shape of electrum (AuAg), filling the voids between chalcopyrite (Cpy) and pyrite (Py), in association with orthoclase (Ort)

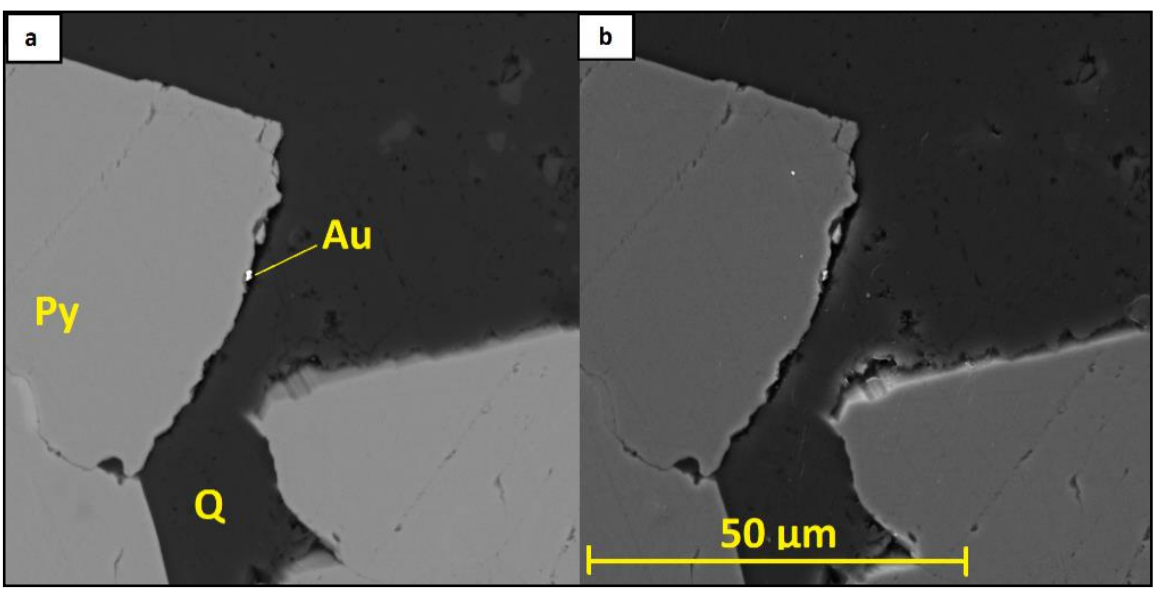

Pис. 4. Изображение сканирующего электронного микроскопа в обратно рассеянных (a) и вторичных (b) электронах, демонстрирующее неправильное зерно золота (Аи), находящееся на периферии пирита (Ру) в кварие $(Q)$

Fig. 4. SEM image in backscattered (a) and secondary (b) electrons showing an irregular gold (Au) grain located at the periphery of pyrite $(P y)$ in quartz $(Q)$

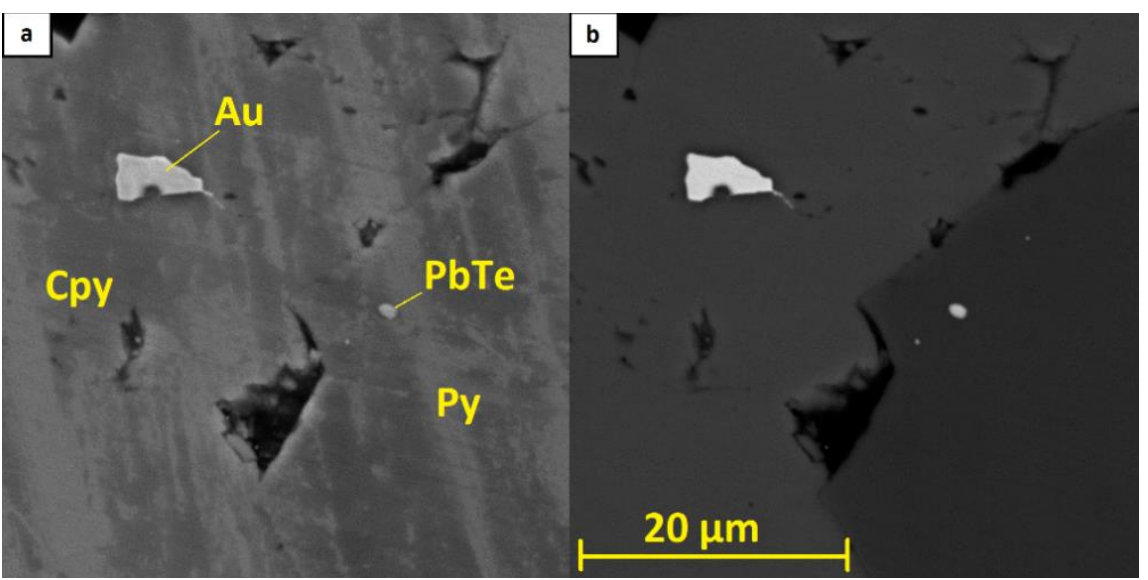

Puc. 5. Изображение сканирующего электронного микроскопа в обратно рассеянных (a) и вторичных (b) электронах, демонстрирующее неправильное зерно золота (Аи) в халькопирите (Сру). Ру - пирит, РbТе-алтаит

Fig. 5. SEM image in backscattered (a) and secondary (b) electrons, showing irregular grain of gold (Au) in chalcopyrite (Cpy). Py-pyrite, PbTe-altaite 


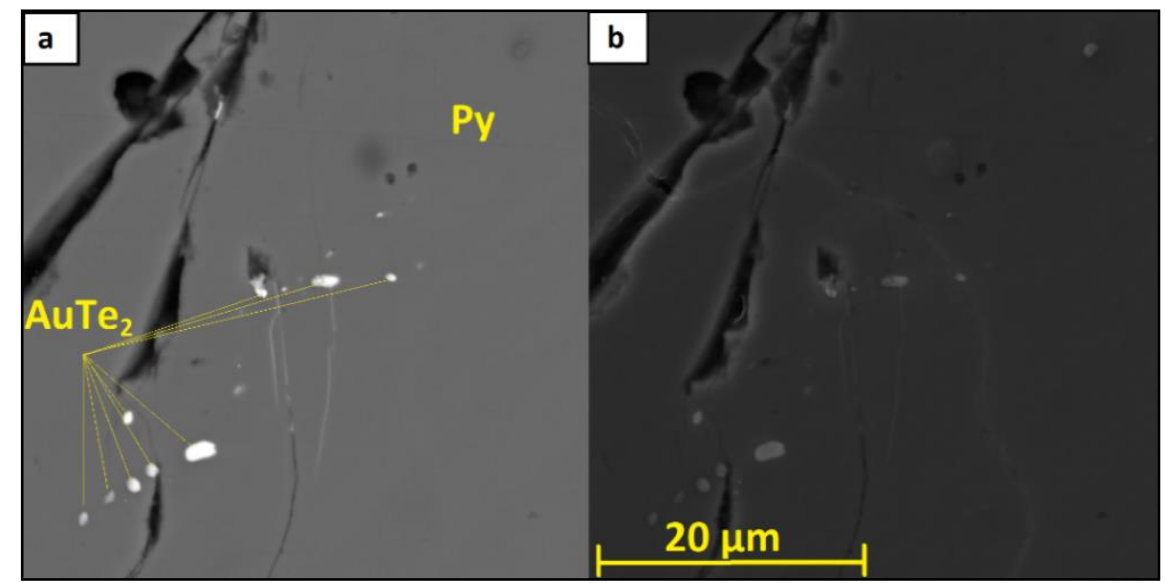

Pис. 6. Изображение сканирующего электронного микроскопа в обратно рассеянных (a) и вторичных (b) электронах, демонстрирующее зёрна калаверита $\left(\mathrm{AuTe}_{2}\right)$ в пирите (Py)

Fig. 6. SEM image in backscattered (a) and secondary (b) electrons, showing grains of calaverite (AuTe $\left.{ }_{2}\right)$ in pyrite (Py)

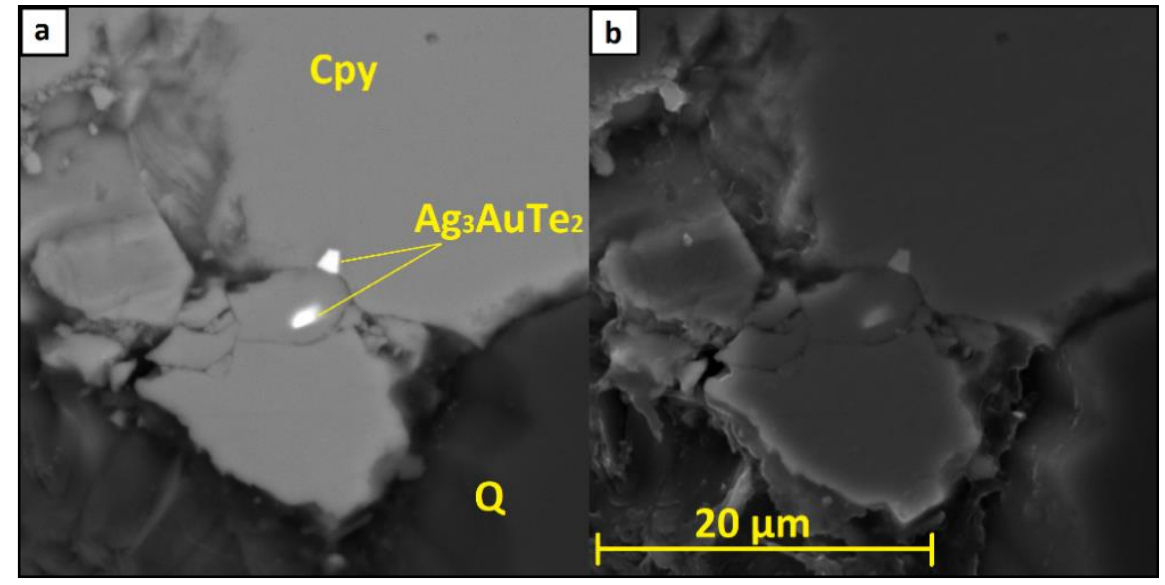

Рис. 7. Изображение сканирующего электронного микроскопа в обратно рассеянных (a) и вторичных (b) электро-

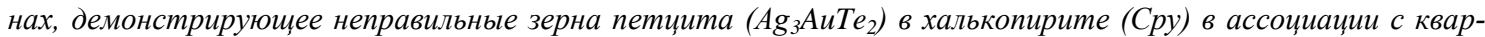
ием $(Q)$

Fig. 7. SEM image in backscattered (a) and secondary (b) electrons showing irregular grains of petzite $\left(\mathrm{Ag}_{3} A u T e_{2}\right)$ in chalcopyrite (Cpy) in association with quartz $(Q)$

Кроме того, установлено, что золото, помимо самородной формы, присутствует в виде тонкодисперсного (размером до 1 микрона), рассеянного - так называемого «невидимого» золота. Для выявления предполагаемого «нанозолота» применялся массспектральный анализ с индуктивно связанной плазмой монофракции пирита [30]. Анализ выявил присутствие рассеянного золота как в сплошных $(0,00054 \%)$, так и во вкрапленных $(0,000049 \%)$ рудах. Данный фактор также является причиной потери 30лота в результате флотации.

\section{Заключение}

Оруденение месторождения Абыз приурочено к зоне березитизации, которая сформирована по вулканогенно-осадочным породам среднего-основного состава, а также их туфогенным производным и осадочным отложениями. По текстурно-структурным особенностям руды представлены двумя типами: в основном сплошными и в подчиненном количестве вкрапленными. Сульфидными минералами являются пирит, халькопирит, галенит и сфалерит.
Проведенными исследованиями установлено, что золотая минерализация тяготеет к сплошным рудам (до 76 \%) и представлена в виде минеральной формы, выраженной прожилковидными выделениями, овальными, неправильными и близкими к изометричной форме включениями в сульфидах, их трещинах, на границах минералов и между ними. Доминирующими минералами-концентраторами в рудах являются такие сульфиды как пирит и халькопирит. Отложение минералов золота происходило в течение двух стадий минералообразования: золото-сульфидной и золототеллуридной. Преобладающим минералом является электрум (AgAu), в меньшей степени диагностируется самородное золото $\mathrm{Au}$, и единично обнаружен петцит $\left(\mathrm{Ag} 3 \mathrm{AuTe}_{2}\right)$ с калаверитом $\left(\mathrm{AuTe}_{2}\right)$. В рудах месторождения Абыз также выявлено «нанозолото». Под этим термином нами понимается тонкодисперсное золото (размером до 1 микрона), рассеянное в пирите.

Таким образом, высокое содержание золота $(4,85$ г/т) в пиритном концентрате можно объяснить тем фактором, что низкопробный золотосодержащий минерал электрум (AgAu) является господствующим 
и развивается по микротрещинам в пирите и халькопирите, а также наличием в руде «нанозолота». При разработке технологической схемы извлечения золота из руды, вероятно, этот фактор не принимался во внимание как при измельчении руды, так и при подборе реагентного режима.

Полученные данные позволяют скорректировать технологическую схему извлечения золота из руды, что в дальнейшем приведёт к повышению извлечения

\section{СПИСОК ЛИТЕРАТУРЫ}

1. Oxidative dissolution of hydrothermal mixed-sulphide ore: an assessment of current knowledge in relation to seafloor massive sulphide mining / E.K. Fallon, S. Petersen, R.A. Brooker, T.B. Scott // Ore Geology Reviews. - 2017. - V. 86. - P. 309-337.

2. Dobretsov N.L. Evolution of structures of the Urals, Kazahstan, Tien Shan and Altai Sayan region within the Ural Mongolian fold belt (Paleoasian ocean) // Russian Geology and Geophysis. 2003. - V. 44. - P. 3-26.

3. Абдулин А.А., Шлыгин А.Е. Металлогения и общие ресурсы Казахстана. - Алма-Ата: Наука, 1988. - 176 с.

4. Мазуров А.К. Металлогенетическое районирование Казахстана // Вестник Томского политехнического университета. 2005. - T. 308. - № 4. - C. 33-39.

5. Tectonic history of the Irtysh shear zone ( NE Kazahstan): new constrains from zircon $\mathrm{U} / \mathrm{Pb}$ dating, apatite fission track dating and palaeostress analysis / S. Glorie, J. De Grave, D. Delvaux, M.M. Buslov, F.I. Zhimulev, F. Vanhaecke, M.A. Elburg, P. Van den haute // Journal of Asian Earth Sciences. - 2012. - V. 44. P. 138-149.

6. Baibatsha A., Dyussembaeva K., Sazhin J. Mineralogical and technological studies of micro- and nanogold deposits of Kazakhstan // 10th International Multidisciplinary Scientific GeoConference. - Bulgaria, 2012. - P. 1181-1186.

7. Минерагеническая карта Казахстана / Л.А. Мирошниченко, Н.М. Жуков, Х.А. Беспаев и др. // Геология Казахстана. 2001. - № 3/4. - С. 73-85.

8. Мазуров А.К. и др. Колчеданные месторождения энсиматических островных дуг Казахстана на примере месторождения Абыз // Известия Томского политехнического университета. Инжиниринг георесурсов. - 2020. - Т. 331. - № 4. - С. 28-37.

9. Щерба Г.Н. Геотектоника и металлогения. - Алма-Ата: Наука, 1988. $-176 \mathrm{c}$.

10. Байбатша А.Б. Модели месторождений благородных металлов. Монография. - Алматы: КазНТУ, 2016. - 452 с.

11. Минералогические особенности рудных диагенитов России / В.В. Масленников, Н.Р. Аюпова, Н.П. Сафина, А.С. Целуйко, И.Ю. Мелекесцева, Р.Р. Лардж, Р.Д. Херрингтон, В.А. Котляров, И.А. Блинов, С.П. Масленникова, С.Г. Тессалина // Минералы. - 2019. - № 9 (3). - С. 1-38.

12. Ferruginous and manganiferous haloes around massive sulphide deposits of the Urals / V.V. Maslennikov, N.R. Ayupova, R.J. Herrington, L.V. Danyushevskiy, R.R. Large // Ore Geology Reviews. -2012 . - V. 47. - P. 5-41.

13. Classification of VMS deposits: lessons from the South Uralides / R. Herrington, V. Maslennikov, V. Zaykov, I. Seravkin, A. Kosarev, B. Buschmann, J.-J. Orgeval, N. Holland, S. Tesalina, P. Nimis, R. Armstrong // Ore Geology Reviews. - 2005 . V. $27(1-4)$. - P. $203-237$

14. Massive sulfides of Mount Jourdan along the super-slow spreading Southwest Indian Ridge and their genesis / B. Nayak, P. Halbach, B. Pracejus, U. Münch // Ore Geology Reviews. - 2014. - V. 63 . P. $115-128$.

15. Mineralogy and geochemistry of metalliferous sedimentary rocks from the upper cretaceous VMS deposits of the eastern pontides (NE Turkey) / M.K. Revan, Y. Genc, O. Delibas, V.V. Maslennikov, N.R. Ayupova, O. Zimitoglu // Turkish Journal of Earth Sciences. - 2019. - V. 28 (2). - P. 299-327.

16. Дюсембаева К.Ш. Минералого-геохимические особенности руд золото-колчеданно-медно-цинкового месторождения Абыз: Центральный Казахстан: дис. ... канд. геол.-минерал. наук. - Алма-Ата, 1992. - 221 с. золота в концентрат и тем самым увеличит рентабельность производства.

Следует отметить, что в результате проведенных исследований в рудах месторождения Абыз впервые диагностированы такие минералы, как калаверит $\mathrm{AuTe}_{2}$, лаутит $\mathrm{CuAsS}$, ильменит $\mathrm{FeTiO}_{3}$, касситерит $\mathrm{SnO}_{2}$, ченгуодаит $\mathrm{Ag}_{9} \mathrm{FeTe}_{2} \mathrm{~S}_{4}$, раклиджит $(\mathrm{Bi}, \mathrm{Pb})_{3} \mathrm{Te}_{4}$, циркон $\mathrm{ZrSiO}_{4}$, монацит $(\mathrm{La}, \mathrm{Ce}, \mathrm{Nd}) \mathrm{PO}_{4}$ и тернемобит (Ce)-(Ce,La, $\mathrm{Nd}) 2 \mathrm{Al}\left(\mathrm{SiO}_{4}\right)_{2}(\mathrm{OH})$.

17. Николаева А.Н., Байболова Ш.Ж. Золото в сульфидных минералах месторождения Абыз / Проблемы геологии и освоения недр: Материалы XXIV Международного симпозиума студентов и молодых ученых имени академика М.А. Усова, посвященного 75-летию Победы в Великой Отечественной войне. Томск: Томский Политехнический университет, 2020. C. $138-140$.

18. Occurrences and distribution of «invisible» precious metals in sulfide deposits from the Edmond hydrothermal field, Central Indian Ridge / Z. Wu, X. Sun, H. Xu, H. Konishi, Y. Wang, C. Wang, Y. Dai, X. Deng, M. Yu // Ore Geology Reviews. 2016. - V. 79. - P. 105-132.

19. Байболова Ш.Ж., Мазуров А.К., Кряжева Т.В. Геология и типы руд месторождения Абыз // Проблемы геологии и освоения недр: Труды XXIII Международного симпозиума им. академика М.А. Усова студентов и молодых ученых, посвященного 120-летию со дня рождения академика К.И. Сатпаева, 120-летию со дня рождения профессора К.В. Радугина. - Томск: Томский Политехнический университет, 2019. - С. 140-142.

20. Родыгина В.Г. Начала минераграфии. - Томск: Изд-во НТЛ, 2006. - $175 \mathrm{c}$.

21. Taylor C.D., Lear K.G., Newkirk S.R. A genetic model for the greens creek polymetallic massive sulfide deposit, admiralty island, southeastern Alaska // US Geological Survey Professional Paper. 2010. - V. 1763. - P. 419-429.

22. Ridge and ultramafic-hosted mineralization: a new type of oceanic $\mathrm{Cu}-\mathrm{Zn}-\mathrm{Co}-\mathrm{Au}$ volcanogenic massive sulfide deposit / Y. Fouquet, P. Cambon, J. Etoubleau, J.L. Charlou, H. Ondreas, F.J.A.S. Barriga, G. Cherkashov, T. Semkova, I. Poroshina, M. Bohn, J.P. Donval, K. Henry, P. Murphy // Rouxel Geophysical Monograph Series. - 2013. - V. 188. - P. 321-367.

23. The enrichment characteristic and mechanism of gold-silver minerals in submarine hydrothermal sulfides from the ultraslowspreading SWIR / Y. Wang, X.-M. Sun, Z.-W. Wu, X.-G. Deng, Y.-Z. Dai, Z.-Y. Lin // Spectroscopy and Spectral Analysis. - 2014. - V. 34 (12). - P. 3327-3332.

24. Ярцев Е.И. Геологическое строение и условия формирования Джусинского колчеданно-полиметаллического месторождения, Южный Урал: дис. ... канд. геол.-минерал. наук. - М., 2017. - $150 \mathrm{c}$

25. German C.R., Von Damm K.L. Hydrothermal processes // Treatise on Geochemistry. - 2003. - V. 6-9. - P. 181-222.

26. Hydrothermal alteration of a $1 \mathrm{~km}$ section through the upper oceanic crust, Deep Sea Drilling Project Hole 504 B: mineralogy, chemistry, and evolution of seawater-basalt interactions / J.C. Alt, J. Honnorez, C. Laverne, R. Emmermann // Journal of Geophysical Research. - 1986. - V. 91. - P. 10309-10335.

27. Bodnar R.J., Vityk M.O. Interpretation of microthermometric data for $\mathrm{HO}-\mathrm{NaCl}$ fluid inclusions // Fluid Inclusions in minerals, methods and applications / Eds. B. de Vivo, M.L. Frezzotti. Blacksburg: Virginia Polytechnic Institute \& State University Publ., 1994. - P. 117-130.

28. Плечов П.Ю. Методы исследования флюидных и расплавных включений. - М.: Изд-во «КДУ», 2014. - 268 с.

29. Cline J.S., Hofstra A.H Ore fluid evolution at the Getchell Carlintype gold deposit, Nevada, USA // European Journal of Mineralogy. - 2000. - V. 12. - P. 195-212.

30. Dill H.G. The «chessboard» classification scheme of mineral deposits: mineralogy and geology from aluminum to zirconium // Earth-Science Reviews. - 2010. - V. 100 (1-4). - P. 1-420.

Поступила 21.10.2021 2. 


\section{Информация об авторах}

Мазуров $\boldsymbol{A . K . , ~ д о к т о р ~ г е о л о г о - м и н е р а л о г и ч е с к и х ~ н а у к , ~ п р о ф е с с о р ~ о т д е л е н и я ~ г е о л о г и и ~ И н ж е н е р н о и ̆ ~ ш к о л ы ~}$ природных ресурсов Национального исследовательского Томского политехнического университета.

Николаева А.Н., аспирант отделения геологии Инженерной школы природных ресурсов Национального исследовательского Томского политехнического университета.

Pудмин М.A., кандидат геолого-минералогических наук, доцент отделения геологии Инженерной школы природных ресурсов Национального исследовательского Томского политехнического университета.

Якич T.Ю., кандидат геолого-минералогических наук, доцент отделения геологии Инженерной школы природных ресурсов Национального исследовательского Томского политехнического университета.

$\boldsymbol{P} \boldsymbol{y \boldsymbol { \sigma } а \boldsymbol { н }} \boldsymbol{A . C .}$., кандидат геолого-минералогических наук, доцент отделения геологии Инженерной школы природных ресурсов Национального исследовательского Томского политехнического университета.

Байболова Ш.Ж., докторант кафедры геологии и разведки месторождений полезных ископаемых Карагандинского государственного технического университета. 
UDC 553.041:553.22

\title{
GOLD IN THE ORE OF THE GOLD-PYRITE DEPOSIT ABYZ (CENTRAL KAZAKHSTAN)
}

\author{
Aleksey K. Mazurov' \\ akm@tpu.ru
}

Anastasiya N. Nikolayeva ${ }^{1}$, nikolaevaanastas759@gmail.com

Maksim A. Rudmin ${ }^{1}$, rudminma@tpu.ru

Tamara Y. Yakich 1 , cherkasovatu@tpu.ru

Aleksey S. Ruban ${ }^{1}$,
ruban@tpu.ru
Shynar Z. Baybolova ${ }^{2}$,
baibolova-sh@mail.ru
${ }^{1}$ National Research Tomsk Polytechnic University,
30, Lenin avenue, Tomsk, 634050, Russia.
2 Karaganda State Technical University,
56/1, Nursultan Nazarbayev avenue, Karaganda, 100027, Kazakhstan.

Relevance of the research. More than 20 gold-pyrite deposits are known in the Chingiz-Tarbogatai structural-formational zone. All deposits have one problem in common: during ore dressing, a significant part of the gold goes into the "pyrite» concentrate and is lost along with the «tailings». In increasing gold recovery, we studied in detail the mineral composition of the ores of the most representative gold-pyrite deposit Abyz. It was found that a significant part of the gold at the deposit is represented by the mineral electrum, which fills microcracks in pyrite and chalcopyrite. When developing a technological scheme for gold extraction, this fact was probably not given due attention, since it was believed that gold in pyrite was represented by native gold.

The main aim is to study textural and structural features of ores, as well as to establish the mineral form of gold in the ores of the Abyz deposit and its relationship to the use of sulfide minerals (pyrite, chalcopyrite, galena and sphalerite).

Research methods included studying the composition of rocks and ores using mineralogical, petrographic, mineragraphic and geochemical analyzes.

Results. Disseminated and solid ores have been identified at the deposit based on their structural and textural properties. It was established that the main amount of gold is associated with solid ores and is presented in mineral form, associated mainly with pyrite and rarely chalcopyrite. Gold mineralization is associated with beresitization; deposition of Au and Ag minerals occurred during the ore stage of mineral formation and related to gold-sulfide and gold-telluride associations. The predominant mineral is electrum AgAu, native gold Au is diagnosed to a lesser extent, and petcite $\mathrm{Ag}_{3} \mathrm{AuTe}_{2}$ with calaverite $\mathrm{AuTe}_{2}$ was found as a single source. The dominant mineralconcentrators in ores are such sulfides as pyrite and chalcopyrite. The reason for the loss of most of the gold as a result of flotation can be explained by the fact that the low-grade gold-bearing mineral electrum AgAu is dominant.

\section{Key words:}

Chingiz-Tarbogatai structural-formation zone, gold-pyrite deposits, sulfides, pyrite, gold, Central Kazakhstan.

\section{REFERENCES}

1. Fallon E.K., Petersen S., Brooker R.A., Scott T.B. Oxidative dissolution of hydrothermal mixed-sulphide ore: an assessment of current knowledge in relation to seafloor massive sulphide mining. Ore Geology Reviews, 2017, vol. 86, pp. 309-337.

2. Dobretsov N.L. Evolution of structures of the Urals, Kazahstan, Tien Shan and Altai Sayan region within the Ural Mongolian fold belt (Paleoasian ocean). Russian Geology and Geophysis, 2003, vol. 44, pp. 3-26. In Rus.

3. Abdulin A.A., Shlygin A.E. Metallogeniya $i$ obshchie resursy Kazakhstana [Metallogeny and general resources of Kazakhstan]. Alma-Ata, Nauka Publ., 1988. 176 p.

4. Mazurov A.K. Metallogenetic zoning of Kazakhstan. Bulletin of the Tomsk Polytechnic University, 2005, vol. 308, no. 4, p. 33-39. In Rus.

5. Glorie S., De Grave J., Delvaux D., Buslov M.M., Zhimulev F.I., Vanhaecke F., Elburg M.A., Van den haute P. Tectonic history of the Irtysh shear zone (NE Kazahstan): new constrains from zircon $\mathrm{U} / \mathrm{Pb}$ dating, apatite fission track dating and palaeostress analysis. Journal of Asian Earth Sciences, 2012, vol. 45, pp. 138-149.
6. Baibatsha A., Dyussembaeva K., Sazhin J. Mineralogical and technological studies of micro- and nanogold deposits of Kazakhstan. $10^{\text {th }}$ International Multidisciplinary Scientific GeoConference. Bulgaria, 2010. pp. 1181-1186.

7. Miroshnichenko L.A., Zhukov N.M., Bespaev Kh.A. Miragenicheskaya karta Kazakhstana [Mineragenic map of Kazakhstan]. Kazakhstan, Geology of Kazakhstan Publ., 2001. Vol. 3-4, pp. 73-85.

8. Mazurov A.K. Pyrite deposits of ensimatic island arcs in Kazakhstan on the example of the Abyz deposit. Bulletin of the Tomsk Polytechnic University. Geo Assets Engineering, 2020, vol. 331, no. 4, pp. 28-37. In Rus.

9. Shcherba G.N. Geotektonika i metallogeniya [Geotectonics and metallogeny]. Alma-Ata, Nauka Publ., 1988. 176 p.

10. Baybatsha A.B. Modeli mestorozhdeniy blagorodnykh metallov: monografiya [Models of deposits of noble metals: monograph]. Almaty, KazNTU Publ., 2016. 452 p.

11. Maslennikov V.V., Ayupova N.R., Safina N.P., Tseluiko A.S., Melekestseva I.Yu., Large R.R., Herrington R.D., Kotlyarov V.A., Blinov I.A., Maslennikova S.P., Tessalina S.G. Mineralogical 
features of ore diagenites in Russia. Minerals, 2019, no. 9 (3), pp. 1-38. In Rus.

12. Maslennikov V.V., Ayupova N.R., Herrington R.J., Danyushevskiy L.V., Large R.R. Ferruginous and manganiferous haloes around massive sulphide deposits of the Urals. Ore Geology Reviews, 2012, vol. 47, pp. 5-41.

13. Herrington R., Maslennikov V., Zaykov V., Seravkin I., Kosarev A., Buschmann B., Orgeval J.-J., Holland N., Tesalina S., Nimis P., Armstrong R. Classification of VMS deposits: Lessons from the South Uralides. Ore Geology Reviews, 2005, vol. 27 (1-4), pp. 203-237.

14. Nayak B., Halbach P., Pracejus B., Munch U. Massive sulfides of Mount Jourdanne along the super-slow spreading Southwest Indian Ridge and their genesis. Ore Geology Reviews, 2014, vol. 63, pp. 115-128.

15. Revan M.K., Genc Y., Delibas O., Maslennikov V.V., Ayupova N.R, Zimitoglu O. Mineralogy and geochemistry of metalliferous sedimentary rocks from the upper cretaceous VMS deposits of the eastern pontides (NE Turkey). Turkish Journal of Earth Sciences, 2019, vol. 28 (2), pp. 299-327.

16. Dyusembaeva K.Sh. Mineralogo-geokhimicheskie osobennosti rud zoloto-kolchedanno-medno-tsinkovogo mestorozhdeniya Abyz: Tsentralny Kazakhstan. Dis. Kand. nauk [Mineralogical and geochemical features of the ores of the gold-pyrite-copper-zinc deposit Abyz: Central Kazakhstan. Cand. Diss.]. Alma-Ata, 1992. $221 \mathrm{p}$

17. Nikolaeva A.N., Baibolova Sh.Zh. Zoloto v sulfidnykh mineralakh mestorozhdeniya Abyz. Problemy geologii i osvoyeniya nedr [Gold in sulfide minerals of the Abyz deposit. Problems of geology and subsoil development]. Materialy XXIV Mezhdunarodnogo simpoziuma studentov $i$ molodykh uchenykh imeni akademika M.A. Usova, posvyashchennogo 75-letivu Pobedy $v$ Velikoy Otechestvennoy voyne [Materials of the XXIV International Symposium of Students and Young Scientists named after Academician M.A. Usov, dedicated to the $75^{\text {th }}$ anniversary of Victory in the Great Patriotic War]. Tomsk, Tomsk Polytechnic University Publ., 2020. pp. 138-140.

18. Demonova A.Yu., Bragin I.V., Razykov B.Kh. Usloviya formirovaniya termomineralnykh vod uygnykh otrogov Gissarskogo khrebta [Conditions for formation of thermomineral waters of the southern spurs of the Gissar Range]. XXI Soveshchanie po podzemnym vodam Sibibri i Dalnego Vostoka [XXI Conference on the Groundwaters of Siberia and the Far East] Novosibirsk, Novosibirsk State University Publ., 2018. pp. 166172.

19. Wu Z., Sun X., Xu H., Konishi H., Wang Y., Wang C., Dai Y., Deng $\mathrm{X} ., \mathrm{Yu}$ M. Occurrences and distribution of «invisible» precious metals in sulfide deposits from the Edmond hydrothermal field, Central Indian Ridge. Ore Geology Reviews, 2016, vol. 79 , pp. 105-132.

20. Baibolova Sh.Zh., Mazurov A.K., Kryazheva T.V. Geologiya i tipy rud mestorozhdeniya Abyz. Problemy geologii i osvoyeniya ned $r$ [Geology and types of ores of the Abyz deposit. Problems of geology and subsoil development]. Materialy XXIII Mezhdunarodnogo simpoziuma imeni akademika M.A. Usova, studentov i molodykh uchenykh, posvyashchennogo 120-letiyu so dnya rozhdeniya akademika K.I. Satpayeva, $k$ 120-letiyu so dnya rozhdeniya professora K.V. Radugina [Proc. of the XXIII International Symposium named after academician M.A. Usov, students and young scientists, dedicated to the $120^{\text {th }}$ anniversary of the birth of academician K.I. Satpayev, to the $120^{\text {th }}$ anniversary of the birth of Professor K.V. Radugin]. Tomsk, Tomsk Polytechnic University Publ., 2019. pp 140-142.

21. Rodygina V.G. Nachala mineragrafii [Beginnings of Mineragraphy]. Tomsk, NTL Publ., 2006. 175 p.

22. Taylor C.D., Lear K.G., Newkirk S.R. A genetic model for the greens creek polymetallic massive sulfide deposit, Admiralty Island, southeastern Alaska. US Geological Survey Professional Paper, 2010, vol. 1763, pp. 419-429.

23. Fouquet Y., Cambon P., Etoubleau J., Charlou J.L, Ondreas H J.L., Barriga F.J.A.S., Cherkashov G., Semkova T., Poroshina I., Bohn M., Donval J.P., Henry K., Murphy P. Ridge and ultramafic-hosted mineralization: a new type of oceanic $\mathrm{Cu}-\mathrm{Zn}-\mathrm{Co}-\mathrm{Au}$ volcanogenic massive sulfide deposit. Rouxel Geophysical Monograph Series, 2013, vol. 188, pp. 321-367.

24. Wang Y., Sun X.-M., Wu Z.-W., Deng X.-G., Dai Y.-Z., Lin Z.-Y. The enrichment characteristic and mechanism of gold-silver minerals in submarine hydrothermal sulfides from the ultraslowspreading SWIR. Guang Pu Xue Yu Guang Pu Fen Xi. Spectroscopy and Spectral Analysis, 2014, vol. 34 (12), pp. 33273332.

25. Yartsev E.I. Geologicheskoe stroyenie i usloviya formirovaniya Dzhusinskogo kolchedanno-polimetallicheskogo mestorozhdeniya, Yuzhnyy Ural. Dis. Kand. nauk. [Geological structure and conditions of formation of the Dzhusinsky pyrite-polymetallic deposit, South Urals Cand. Diss.]. Moscow, 2017. 150 p.

26. German C.R., Von Damm K.L. Hydrothermal Processes. Treatise on Geochemistry, 2003, vol. 6-9, pp. 181-222.

27. Alt J.C., Honnorez J., Laverne C., Emmermann R. Hydrothermal alteration of a $1 \mathrm{~km}$ section through the upper oceanic crust, Deep Sea Drilling Project Hole 504 B: mineralogy, chemistry, and evolution of seawater-basalt interactions. Journal of Geophysical Research, 1986, vol. 91, pp. 10309-10335.

28. Bodnar R.J., Vityk M.O. Interpretation of microthermometric data for $\mathrm{HO}-\mathrm{NaCl}$ fluid inclusions. Fluid Inclusions in Minerals. Methods and Applications. Eds. De Vivo B., Frezzotti M.L. Blacksburg, Virginia Polytechnic Institute \& State University Publ., 1994. pp. 117-130

29. Plechov P.Yu. Metody issledovaniya flyuidnykh i rasplavnykh vklyucheniy [Methods for the study of fluid and melt inclusions]. Moscow, KDU Publ. house, 2014. 268 p.

30. Cline J.S., Hofstra A.H. Ore fluid evolution at the Getchell Carlintype gold deposit, Nevada, USA. European Journal of Mineralogy, 2000, vol. 12. pp. 195-212

31. Dill H.G. The «chessboard» classification scheme of mineral deposits: Mineralogy and geology from aluminum to zirconium. Earth-Science Reviews, 2010, vol. 100 (1-4), pp. 1-420.

Received: 21 October 2021.

\section{Information about the authors}

Aleksey K. Mazurov, Dr. Sc., professor, National Research Tomsk Polytechnic University.

Anastasiya N. Nikolayeva, postgraduate student, National Research Tomsk Polytechnic University.

Maksim A. Rudmin, Cand Sc., associate professor, National Research Tomsk Polytechnic University.

Tamara Y. Yakich, Cand Sc., associate professor, National Research Tomsk Polytechnic University.

Aleksey S. Ruban, Cand Sc., associate professor, National Research Tomsk Polytechnic University.

Shynar Z. Baybolova, doctoral student, Karaganda State Technical University. 